\title{
Légi hiperspektrális felvétel osztályozási pontosságának vizsgálata fás mintaterületen
}

\author{
LIKÓ Szilárd Balázs - BEKÓ László - BURAI Péter - MARI László
}

DOI: $10.30921 / G K .73 .2021 .3 .2$

Absztrakt: Jelen kutatásunkban osztályozási technikákat vizsgáltunk hiperspektrális légi felvételen, különbözố fafajok elkülönitésének céljával. A különbözó módszerek alapját két képi jelerôsítô transzformációtípus (PCA fökomponens analizis, MNF - legkisebb zajhatású rész) és három irányított pixelalapú képosztályozási algoritmus (ML - Maximum Likelihood, SVM - Support Vector Machine, RF - Random Forest) és ezek kombinációja adta. A vizsgált terület egy a Mecsek lábánál elterüló dombos terület volt. A legmagasabb osztályozási pontosságot 81,16\%-kal az MNF transzformált csatornákon elvégzett SVM-osztályozás hozta, 10 különbözó fafaj esetén, egy közel két négyzetkilométeres mintaterületen. Ezt követöen a meghatározott leghatékonyabb osztályozót kiterjesztettük a teljes felvételezett területre $\left(13 \mathrm{~km}^{2}\right)$, amelyen az 70,20\%-os teljes pontossági értéket mutatott, immáron 16 különbözó fafajnál.

Abstract: In this paper, we are investigating the methodical work on classifying hyperspectral images, on a purpose to identify tree species. For this, we are testing two transformation method: PCA (Principal Component Analysis), MNF (Minimum Noise Fraction), and three classification variety ML (Maximum Likelihood), SVM (Support Vector Machine), RF (Random Forest) to find the best combination of these and the ideal number of bands used on classification. The investigated area took place in Hungary around Mecsek, in a hilly area. Our final result was an 81,16\% overall accuracy value, with ten tree species, with MNF SVM combination, on an image cut around $2 \mathrm{~km}^{2}$. After finding the best combination, we spread our research on a larger $\left(13 \mathrm{~km}^{2}\right)$ area, resulting in $70,20 \%$ overall accuracy with 16 tree species there.

Kulcsszavak: hiperspektrális légi felvétel, vegetációtérképezés, Maximum Likelihood Classifier (MLC), Random Forest (RF), Support Vector Machine (SVM)

Keywords: Aerial hyperspectral imagery, vegetation mapping, Maximum Likelihood Classifier (MLC), Random Forest (RF), Support Vector Machine (SVM)

\section{Bevezetés}

Az erdôk fáinak faji összetétele igen meghatározó lehet több szempontból is, ilyen az erdészeti alkalmazás, a fa alapanyag mennyiségi becslése, a biomasszabecslés, a természetvédelem különbözó területei, például az invazív fafajok elterjedésének vizsgálata. Nem utolsósorban a klímaváltozás vizsgálatának is egyik alapja lehet az erdôk faji összetételének, területi elterjedésének a változása és ennek a nyomon követése. Ez a szempont a 21 . század egyik lényeges kutatási területévé teszi az erdôket, nem csak kizárólag hazánkban. Számos kutatás zajlik a világ minden részén, kiemelve a trópusi erdôket, melyek rendkívül érzékenyek a környezeti változásokra, és ez fokozódni fog a jövóben is (Clark et al. 2005). A kutatás célja egy fafajtérkép létrehozása egy erdőrészletrốl a Mecsek lábánál, mely térkép a lombkorona szintjén elterülố fajokról ad információt. A kutatás során egy légi hiperspektrális felvételt dolgoztunk fel, melyet az Mecsekerdó Zrt. biztosított számunkra. Ezen a felvételen, a mintaterületen lévố fafajok szerinti osztályozás volt a cél, különös tekintettel arra, hogy milyen irányított osztályozási algoritmussal, illetve milyen és mennyi transzformált spektrális csatornával érhetó el a legnagyobb osztályozási pontosság. A nemzetközi szakirodalomban sincs egyöntetú válasz a fafajok elkülönítésére leginkább alkalmas transzformációk, alkalmazandó csatornaszámok és osztályozóalgoritmusok tekintetében. (Belgiu-Drăgut 2016, Melgani-Bruzzone 2004, Clark et al. 2005, Latifi et al. 2012). Ugyanakkor hazai kutatások is jellemzik a szakterületet. Burai et al. 2019-es kutatásában egy úgynevezett objektumalapú osztályozási módszert dolgozott ki, mely pontosabb és átláthatóbb fafajtérképet eredményezett. Burai et al. 2014-es kutatásában három különbözó osztályozási módszert tesztelt az energianövények feltérképezésére; a legnagyobb osztályozási pontosságot a bináris döntési fán alapuló support vector machine
(SVM) osztályozás hozta. Deák et al. 2017-es kutatásában múholdfelvételek segítségével vizsgálta a Budaihegység erdôségét; a kutatás során kevert osztályokat hoztak létre a felvétel pixelmérete $(30 \mathrm{~m})$ okozta keveredés elkerülése végett, lépésenkénti diszkriminanciaanalízist (SDA) használtak adatcsökkentés céljából, és SVM-osztályozást végeztek. A módszer magasabb teljes osztályozási pontosságot eredményezett, mint a hagyományos fôkomponens-analízis SVM-osztályozással kombinálva.

\section{Anyag és módszer}

\section{A mintaterület bemutatása}

A vizsgált mintaterület a Mecsekerdô Zrt. múködési területén, a KözépMecsekben, Pécstől északra helyezkedik el közel $14 \mathrm{~km}^{2}$-en (4608'06,90" É, $18^{\circ} 15^{\prime} 55,60$ ” K). A hiperspektrális felvételekből készített mozaik - a látható színtartományban - az 1. ábrán látható, a kiválasztott $2 \mathrm{~km}^{2}$-es mintaterülettel együtt. Az Erdőállomány Adattár (az erdôtérkép hivatalos honlapja) 


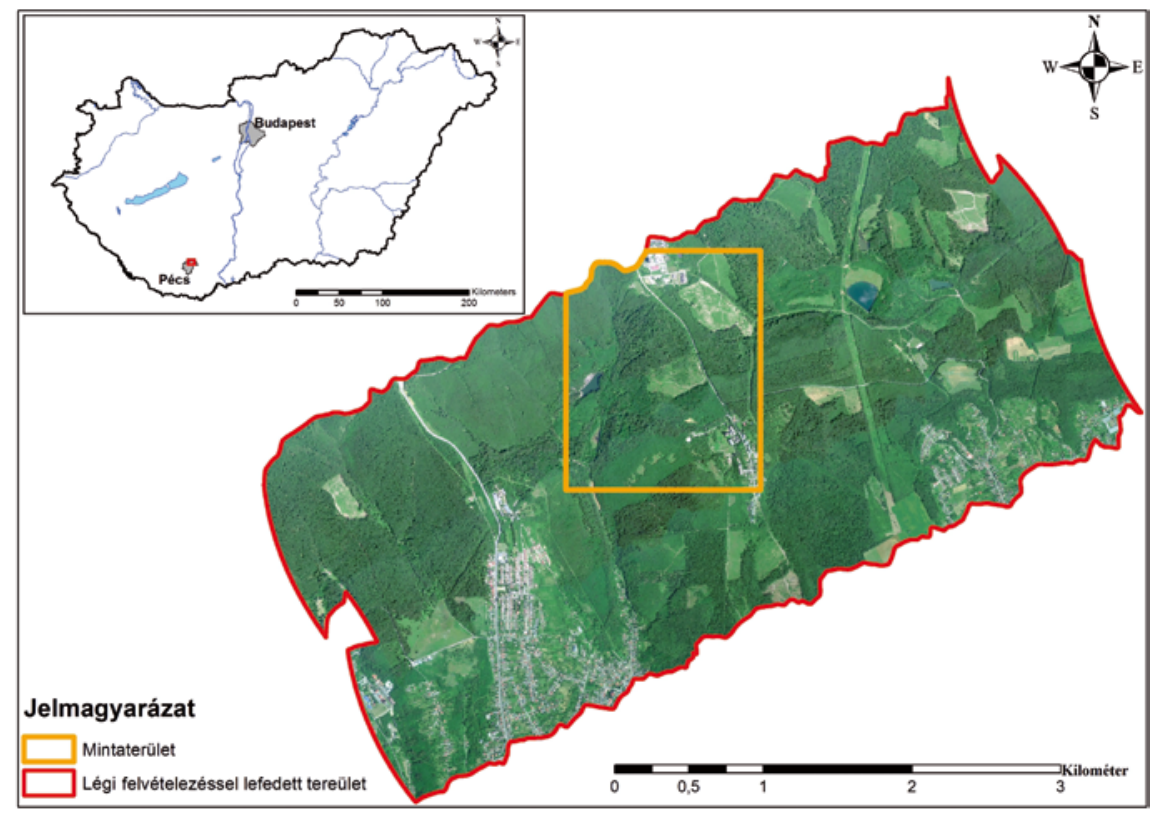

1. ábra. A teljes vizsgálati terület és a kivágott mintaterület elhelyezkedése (saját szerkesztés)

az ilyen összetett, sok fás szárú fajt tartalmazó erdôs területek pixelalapú osztályozásának sikerességéhez. A különbözố szakirodalmi forrásokban gyakran alkalmaznak ehhez hasonló, nagy térbeli felbontást (Burai et al. 2019, Clark et al. 2005, Tarabalka et al. 2010).

A terepi adatgyújtés során precíziós GPS-eszköz segítségével az adott fafajhoz tartozó egyedek helykoordinátái kerültek rögzítésre, melyekből az irányított osztályozásokhoz szükséges tanító- és ellenôrzố területek álltak elô. A felmért pontokat a területen elszórtan, jól megközelíthetô és azonosítható helyen jelöltük meg. Mivel a területen is egyenlőtlen eloszlásúak az egyes fafajok, ezért a felvett tanítóterületek pixelszáma is különbözô.

és a felvételen látható lombkoronák alapján, valamint terepi adatgyújtéssel a helyi szakemberek segítségével 16 fafaj került megkülönböztetésre, melyek tanító- és ellenôrzố területi eloszlása, illetve az osztályozás során felhasznált kódja az 1. táblázatban látható

A vizsgált 16 fafaj közül 11 megtalálható a kivágott mintaterületen, melyek megkülönböztetô jelöléssel (szürke háttérrel) rendelkeznek a táblázatban. Ezen osztályokból a mintaterület és a teljes terület osztályozása során felhasznált tanító- és ellenôrzô területek elkülönülve láthatóak a táblázatban.

\section{Felhasznált adatok}

A területet lefedô hiperspektrális légifelvétel-mozaik három lerepült sávból áll, melyek között az átfedés 30\%-os, ami a torzulásmentes kép létrehozásához szükséges. A felvételeket a Mecsekerdô Zrt. bocsátotta a rendelkezésünkre. A három sávból álló mozaik 13,965km² kiterjedésú területet fed le, de a limitált számítási kapacitás miatt az osztályzások teszteléséhez egy $2,03 \mathrm{~km}^{2}$ kiterjedésû mintaterületet használtunk fel. A felvétel spektrális tartománya 400-2500 nm közé esik, és 420 spektrális csatornát tartalmaz. A légi felvétel terepi felbontása $1 \mathrm{~m}$. Ez a részletesség szükséges

\section{Képfeldolgozás}

A nyers felvételek előfeldolgozása során geometriai és atmoszférikus korrekciót alkalmaztunk. Vizuális interpretáció alapján, a felvételen látható zajos, zavaros csatornákat eltávolítottuk, melyek a számos spektrális csatorna és a különböző légköri viszonyok következtében gyakran fellelhetôek hiperspektrális légi felvételek esetében (Rasti et al. 2018). Ennek eredményképpen a megtartott csatornák túlnyomó része a VNIR(visible near infrared) tartományba esett, amely 400-1000 nm-ig terjed, azaz a látható és a közeli infravörös tartományt jelenti. Ebból adódóan

\begin{tabular}{|c|c|c|c|c|}
\hline Fafajkód & Magyar név & Latin név & $\begin{array}{c}\text { Tanítóterület } \\
\text { (pixelszám) } \\
\text { Mintaterület/teljes }\end{array}$ & $\begin{array}{c}\text { Ellenórzó terület } \\
\text { (pixelszám) } \\
\text { Mintaterület/teljes }\end{array}$ \\
\hline $\mathbf{A}$ & Fehér akác & Robinia pseudoacacia & $1197 / 344$ & $600 / 76$ \\
\hline $\mathbf{B}$ & Közönséges bükk & Fagus sylvatica & $153 / 626$ & $67 / 168$ \\
\hline BL & Mirigyes bálványfa & Ailanthus altissima & $578 / 263$ & $331 / 80$ \\
\hline BL_msz & Mirigyes bálványfa (magszóró) & Ailanthus altissima & $139 / 588$ & $17 / 248$ \\
\hline CS & Csertölgy & Quercus cerris & $0 / 513$ & $0 / 167$ \\
\hline CSNY & Madárcseresznye & Cerasus avium L. & $245 / 209$ & $65 / 79$ \\
\hline EH & Ezüst hárs & Tilia tomentosa & $150 / 317$ & $66 / 76$ \\
\hline FF & Feketefenyố & Pinus nigra & $0 / 241$ & $0 / 81$ \\
\hline GY & Közönséges gyertyán & Carpinus betulus L. & $83 / 897$ & $44 / 233$ \\
\hline $\mathbf{H J}$ & Hegyi juhar & Acer pseudoplatanus & $94 / 32$ & $27 / 30$ \\
\hline KST & Kocsányos tölgy & Quercus robur $L$. & $270 / 154$ & $76 / 26$ \\
\hline KTT & Kocsánytalan tölgy & Quercus petraea & $381 / 1555$ & $134 / 314$ \\
\hline LF & Lucfenyố & Picea abies $L$. & $67 / 66$ & $27 / 17$ \\
\hline MOT & Molyhos tölgy & Quercus pubescens & $0 / 169$ & $0 / 54$ \\
\hline VF & Vörösfenyô & Larix decidua & $0 / 84$ & $0 / 37$ \\
\hline VK & Virágos kőris & Fraxinus ornus & $0 / 119$ & $0 / 22$ \\
\hline
\end{tabular}


158 csatorna került további felhasználásra 442,51 nm és $1082,76 \mathrm{~nm}$ között. Ezen tartományon belül is fellelhetôek voltak zajos csatornák, fôképpen a 950 nm-es hullámhossz környezetében.

A képosztályozások megkezdése elốtt képi jelerôsítô és adatcsökkentési eljárásokat alkalmaztunk, ilyen a PCA-(Principal Component Analysis) transzformáció, mely az analízis során ortogonális transzformáció segítségével választja ki a legkevésbé korreláló változókat, amik a legjobban elkülönítik és jellemzik a mért adatot, jelen esetünkben a sávokat (Latifi et al. 2012), így megkapjuk a főkomponenseket, amelyek információtartalmuk alapján vannak sorba rendezve. Ehhez hasonló az MNF- (Minimum Noise Fraction) transzformáció, mely két fớkomponens-transzformációból áll össze; az elsố kiemeli a spektrális zajt a zaj kovaranciamátrixa segítségével, a második pedig prioritást ad az így megmaradt sávoknak, a jelerôsség alapján (Hamada et al. 2007).

Ezen eljárásokat azért alkalmazzuk, mert a hiperspektrális felvételek gyakran hordoznak redundáns spektrális információt, mely különböző statisztikai módszerekkel alátámasztható, így a sávok jelentôs része erôsen korrelál egymással (Zhang-Xie 2012). Így az adat feldolgozhatósága és a számítási kapacitás csökkentése érdekében ezekhez hasonló dimenziócsökkentési eljárásokat lehet alkalmazni. A transzformáción átesett csatornák nem rendelkeznek hullámhossz-attribútummal, hiszen ezek az algoritmusok a teljes adatkészlet (jelen esetben a spektrális tartomány) információját tömörítik, és sorolják be a transzformált csatornákba. Mivel az osztályozásokhoz szükséges tanítóterületek fafajonként különbözô mennyiségú pixelt tartalmaztak, így egyes osztályok felülreprezentáltak lehetnek a több tanítóterület következtében. Tehát a több tanítóterülettel rendelkezô osztályok magasabb osztályozási pontosságot mutathatnak, így a fafaj osztályozhatósága a valósnál jobb értéket mutathat a többi fajhoz képest. Ennek a kiküszöbölésére az egyes osztályokból 100 véletlenszerú pixelt használtunk fel az osztályozások során, amely érték közelebb hozza a tanítóterületek mennyiségét, ugyanakkor elég a jó az osztályozás kivitelezéséhez. A hegyi juhar, lucfenyố és közönséges gyertyán osztályok esetében a tanítóterületek nem érték el a 100 pixelt, ezeknél a maximum került felhasználásra.

A munka során három különbözô osztályozási algoritmust teszteltünk, melyek az ML (Maximum Likelihood), SVM (Support Vector Machine) és az RF (Random Forest) voltak. Az ML-algoritmus az osztályozás során minden meghatározott osztályra szórást és kovaranciamátrixot alkalmaz, hogy az adatok bizonyos csoportokba kerülési esélyét számítsa (Clark et al. 2005). Az SVM egy több dimenziós „hipersík” segítségével választja szét az adat pixeleit, és hozza létre az osztályokat; a hipersík akkor van jól elhelyezve, ha maximalizálja a legközelebbi tanulóadat és az elválasztó sík közötti távolságot (Richter et al. 2016). Az RF egy nem parametrikus osztályozási algoritmus, amely egy bináris döntési fát épít fel, s ezeken a döntéseken egyesével végighaladva helyezi egyre homogénebb osztályokba az adat pixeleit (Richter et al. 2016). Az osztályozások során kapott eredményeket klasszikus tematikus pontossági mutatókkal vizsgálatuk és értékeltük. Ilyen a teljes pontosság (OA), az előállítói pontosság (PA) és a felhasználói pontosság (UA). A teljes pontosság megvizsgálja, hogy az osztályozással létrehozott kategóriák mennyire térnek el a valóságtól. Ezt ellenőrző területekkel teszi, és százalékos eredményt ad, melynél 100\% az elméleti teljes pontosság. Az elôállítói pontosság azt fejezi ki, hogy egy adott osztályozott pixel mekkora eséllyel került jó osztályba. A felhasználói pontosság annak százalékos arányát fejezi ki, hogy az adott osztályhoz tartozó kontrollterület hányad része lett valóban abba az osztályba sorolva az osztályozás során (Harris geospatial solutions inc. hivatalos honlapja).

\section{Eredmények és kiértékelésük}

Az egyik legfontosabb eredmény a legmagasabb pontosságot adó osztályzási típus, illetve transzformáció kiválasztása, melyhez a 2. ábra nyújt segítséget, ahol az egyes osztályozási kombinációk teljes pontossága (OA) látható a csatornaszám függvényében. Az adatot az ellenôrzố területek segítségével konfúziós mátrixokból állítottuk elö.

A legjobb eredményt az MNF transzformált csatornákon elvégzett SVM-osztályozó eredményezte, a maximumot az elsô 8 csatorna felhasználásával érte el, 77,65\%-os teljes pontossággal. A 2 . ábrán jól látható, hogy nem csak a maximum esetében, de minden csatornaszámnál ez a típus hozta a legjobb eredményeket. Az MNF transzformált csatornákon alkalmazott RF-osztályozás 72,21\%-os maximális teljes pontosságot mutat.

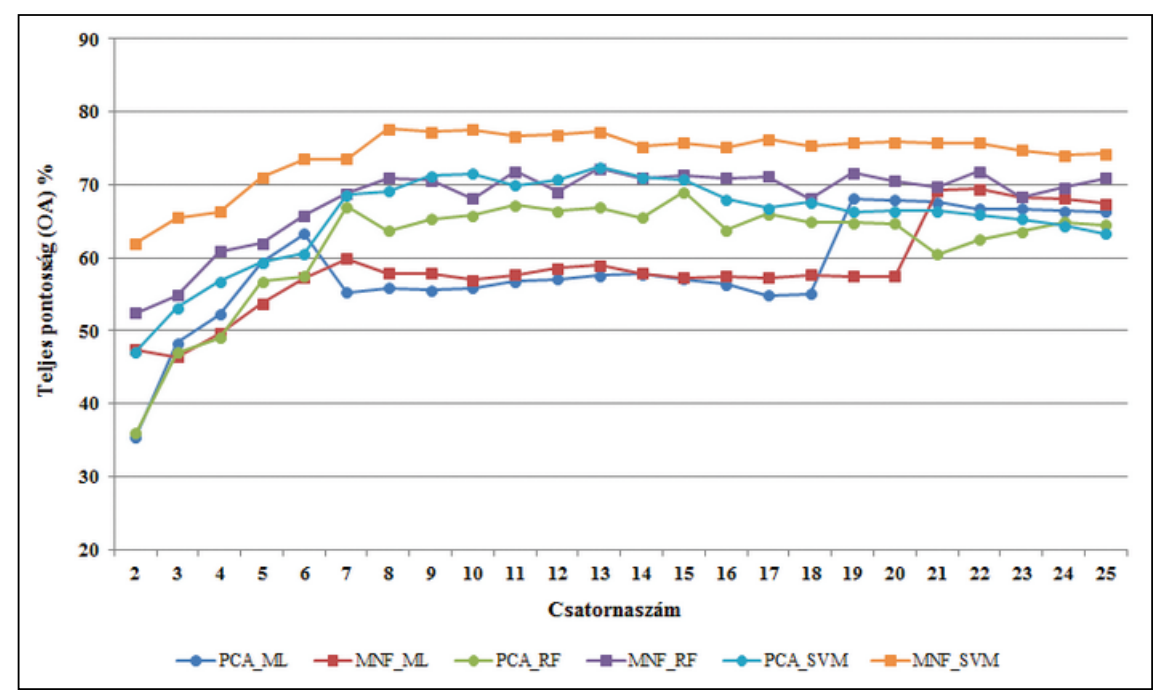

2. ábra. Az egyes osztályozási és transzformációtípusok teljes pontosságának diagramon való ábrázolása 
Leggyengébb eredményt az ML-típusú osztályozások hozták, melynél úgyszintén az MNF-transzformáción átesett csatornák osztályozása volt hatékonyabb, 69,39\%-os teljes pontossági értékkel, 22 felhasznált csatornánál.

Az osztályozások során az is kiderült, hogy mindhárom osztályozás esetében a maximális teljes pontosságot tekintve az MNF transzformált csatornák jobb eredményt hoztak, mint a PCA-transzformáción átesettek. Egyik típus sem éri el a $80 \%$-os teljes pontossági értéket; ennek több oka is lehet, egyrészt a tanítóterületek mennyisége, mivel irányított osztályozási algoritmusokról van szó, melyeknek alapvetô összetevője a tanítópixelek, s a pixelszámok növelésével a hatékonyságuk is növelhetô. Az egyes osztályok felülreprezentáltsága miatt 100 pixelben maximáltuk a tanítóterületeket, mely befolyásolta az eredményt, hiszen a tanítóterületek mérete egy fontos összetevôje az irányított osztályozási algoritmusoknak. Ennek bizonyítására a leghatékonyabb osztályozást, tehát a 8 MNFcsatornán történô SVM-osztályozást lefuttattuk a maximális rendelkezésre álló tanítóterületekkel is. Habár az eredmény az osztályok közötti torzulással is járhat, a 78,61\%-os értékkel majdnem egy százalékpontot növekedett a teljes pontosság. További eredményjavító lehetôséget rejt magában az egyes kevert osztályok egyesítése, mint a bálványfa, illetve a magszóró bálványfa, ugyanis ezek megkülönböztetése igen nehézkes, a két osztály egybevonásával az osztályozás teljes pontossága $81,16 \%$-ra növekedett.

A 3. ábrán látható a legnagyobb teljes pontosságot adó osztályozott kép. A képrôl a legszembetúnôbb az akácosok jelentős elterjedése, mely egy invazív fafaj és nagy problémát jelent a területen, jellemzốen a hazai erdeinkben, a gyors és agresszív elterjedése miatt. Nagy veszélyforrást jelent, mivel ahol megjelenik, ott kiszoríthatja az egyéb, ôshonos fajokat. Fôként erdôfelújításokban és fiatal faegyedek fejlôdésénél okoz problémát. Ezen okokból következôen a detektálása, területi elterjedésének vizsgálata fontos természetvédelmi

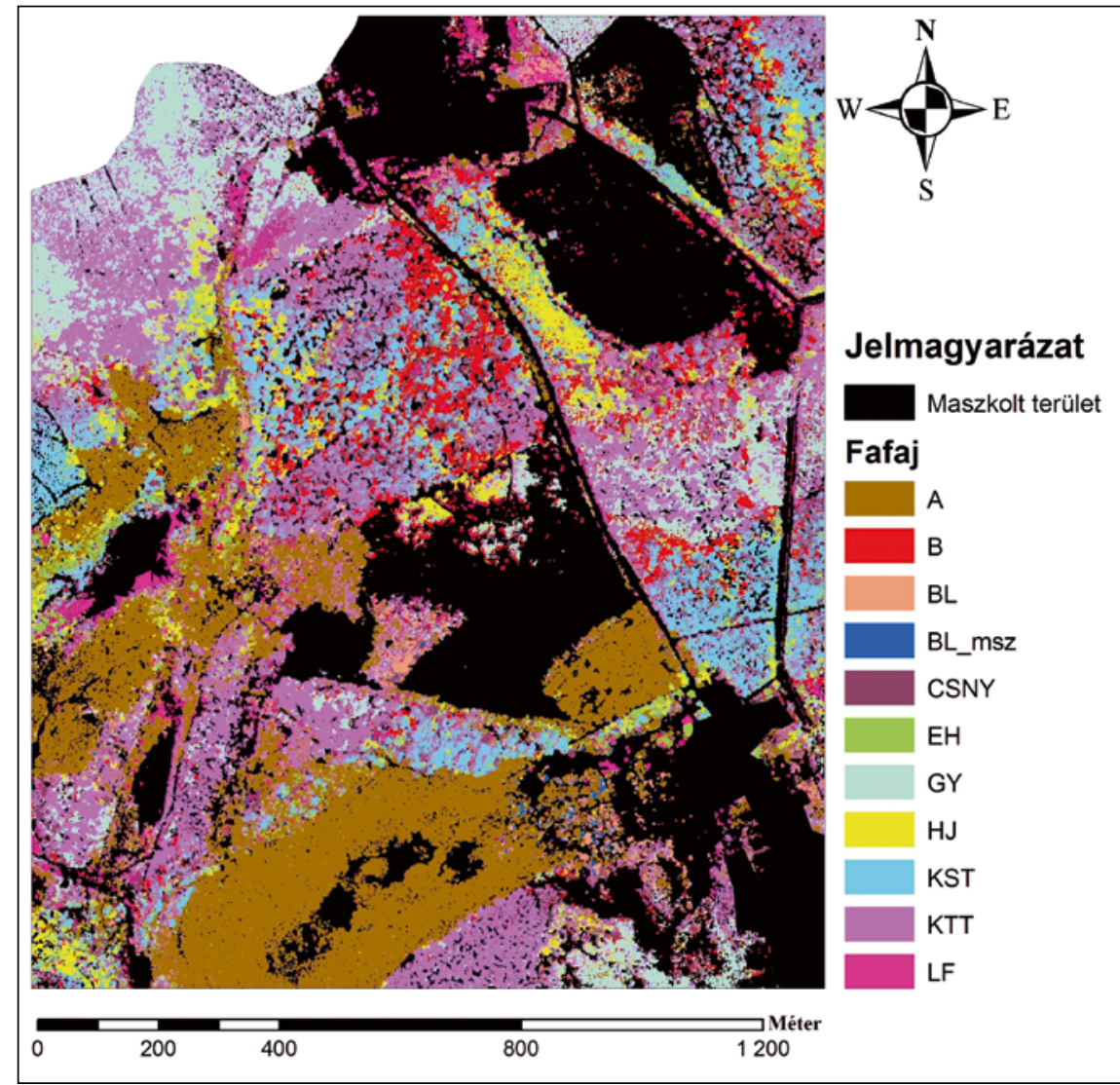

3. ábra. A legnagyobb teljes pontosságot elért osztályozás eredménye (MNF-transzformáció 8 csatornája SVM-osztályozással)

szempontból, osztályozásának módszertana további és folyamatos fejlesztést igényel (Kovács et al. 2019). Az akácként osztályozott területen (barna szín a képen) fơként fiatalabb állományú (10-15 éves) akácosok találhatóak. Az akácpixelek között megjelenố egy-egy más osztályba tartozó pixelek, valószínúleg a hibásan osztályozott pixelek, hiszen a felsố lombkoronaszinten zajlik az osztályzás, és az akácállomány lombkoronája zártnak tekinthetố. Egy-egy pixel mégis hibásan jelentkezhet a lombkoronák közötti árnyékos, kevert reflektanciájú területeken, s mivel a pixelméret $1 \times 1$ méter, valószínúbb a hiba, mint az egyéb közbeékelôdô kisebb lombkoronával rendelkezô fák jelenléte.

Az osztályozási pontosság eredményeinek jobb megértése és az osztályok keveredésének az ellenôrzése végett a 2. táblázatban a $8 \mathrm{MNF}$ transzformált csatornán elvégzett SVM-osztályozás hibamátrixa látható, mely az ellenôrzési folyamat során alkalmazott konfúziós mátrixokból nyert adatokat tartalmaz. A hibamátrix fôátlójában az egyes osztályok elốállítói pontossági (helyes besorolás) értékei láthatóak hasonló színezéssel, a fóátlón kívül pedig az egyes osztályok keveredése (hibás besorolás) százalékban kifejezve.

A hibamátrix alapján a legalacsonyabb osztályozási pontossága a magszóró bálványfának (BL_msz) volt $(\mathrm{PA}=47,06 \%)$, ami leginkább a nem magszóró bálványfákkal (BL) keveredett 35,29\%-ban. Ez a gyakorlatban nem okoz nagy gondot, mivel egy fafajba tartoznak, viszont a madárcseresznyével (CSNY) is keveredett 17,65\%-ban, ami már a terepi inváziós kezelés szempontjából problémát okozhat. Több másik osztály esetében is $10 \%$ feletti keveredést tapasztaltunk a bálványfa esetében, nevezetesen a bükk (B), gyertyán (GY) és a madárcseresznye kategóriáknál, mely alapján kijelenthető, hogy az eredménytérképen a bálványfa felülreprezentált. Kiugró érték látható a gyertyán esetében is, ami leginkább a közönséges bükk osztállyal keveredett. Érdekesség ezzel kapcsolatban, hogy a bükk osztály más fafajokkal 
Likó Szilárd et al.: Légi hiperspektrális felvétel osztályozási pontosságának vizsgálata fás mintaterületen

\begin{tabular}{|ccccccccccccc|}
\hline Oszt lyok & B & HJ & EH & KST & LF & KTT & GY & CSNY & A & BL_msz & BL \\
B & 70,15 & 0,00 & 0,00 & 0,00 & 0,00 & 0,00 & 31,82 & 0,00 & 0,00 & 0,00 & 0,60 \\
HJ & 0,00 & 92,59 & 0,00 & 3,95 & 0,00 & 0,00 & 0,00 & 0,00 & 0,33 & 0,00 & 1,21 \\
EH & 0,00 & 0,00 & 96,97 & 3,95 & 0,00 & 0,00 & 0,00 & 0,00 & 0,00 & 0,00 & 0,30 \\
KST & 0,00 & 7,41 & 0,00 & 75,00 & 0,00 & 0,00 & 0,00 & 0,00 & 0,67 & 0,00 & 1,51 \\
LF & 0,00 & 0,00 & 0,00 & 0,00 & 92,59 & 0,00 & 0,00 & 0,00 & 0,00 & 0,00 & 0,60 \\
KTT & 8,96 & 0,00 & 0,00 & 11,84 & 0,00 & 69,40 & 0,00 & 13,85 & 0,00 & 0,00 & 0,00 \\
GY & 2,99 & 0,00 & 0,00 & 0,00 & 0,00 & 16,42 & 65,91 & 4,62 & 0,33 & 0,00 & 0,00 \\
CSNY & 4,48 & 0,00 & 0,00 & 2,63 & 0,00 & 13,43 & 2,27 & 67,69 & 0,83 & 17,65 & 10,88 \\
A & 0,00 & 0,00 & 3,03 & 2,63 & 0,00 & 0,00 & 0,00 & 1,54 & 81,33 & 0,00 & 0,00 \\
BL_msZ & 0,00 & 0,00 & 0,00 & 0,00 & 0,00 & 0,00 & 0,00 & 0,00 & 0,17 & 47,06 & 9,67 \\
BL & 13,43 & 0,00 & 0,00 & 0,00 & 7,41 & 0,75 & 0,00 & 12,31 & 16,33 & 35,29 & 75,23 \\
\hline
\end{tabular}

2. táblázat. Hibamátrix a 8 MNF transzformált csatornán futtatott SVM-osztályozás eredményéböl

nem, vagy csak kismértékben keveredett. Az említettekkel ellentétben a hegyi juhar (HJ), ezüst hárs (EH) és lucfenyô (LF) osztályok esetében magas elôállítói pontosság látható, e három osztály esetében $90 \%$ feletti az ellenőrző területeken a jól osztályozott pixelek aránya, a keveredés mértéke csekély, ami megbízható elkülöníthetôséget jelez.

\section{A teljes terület vizsgálata}

Az előző fejezetben bemutatott kutatási folyamat során feltárt leghatékonyabb osztályozási módszert, tehát az MNF-csatornákon történô SVMosztályozást a teljes területen is teszteltük. A terület majdnem a hétszerese az előzőekben bemutatottnak, ezzel együtt az osztályozásba is 5 további fafajt vontunk be, így összesen 16 osztály került megkülönböztetésre. Az osztályozás teljes pontossága 70,20\% volt, $18 \mathrm{MNF}$ transzformált csatorna felhasználásával. A 4. ábrán a megjelölt 16 fafaj térbeli mintázata látható, melybốl a legjobban kitûnố az akác (A), a kocsánytalan tölgy (KTT) és a gyertyán (GY).

\section{Eredményekból levont következtetések}

Azonos bemeneti adattal a különbözô osztályozó algoritmusok különbözố eredményt mutatnak. Habár ez a felvetés magától értetôdőnek látszik, megindokolja miért is lényeges a megfelelố osztályozási módszert kiválasztani, a minél jobb eredmény elérése érdekében. A transzformációk közül az MNF mindhárom megvizsgált osztályozásnál jobb eredményt hozott, mint a PCA-típusú, a

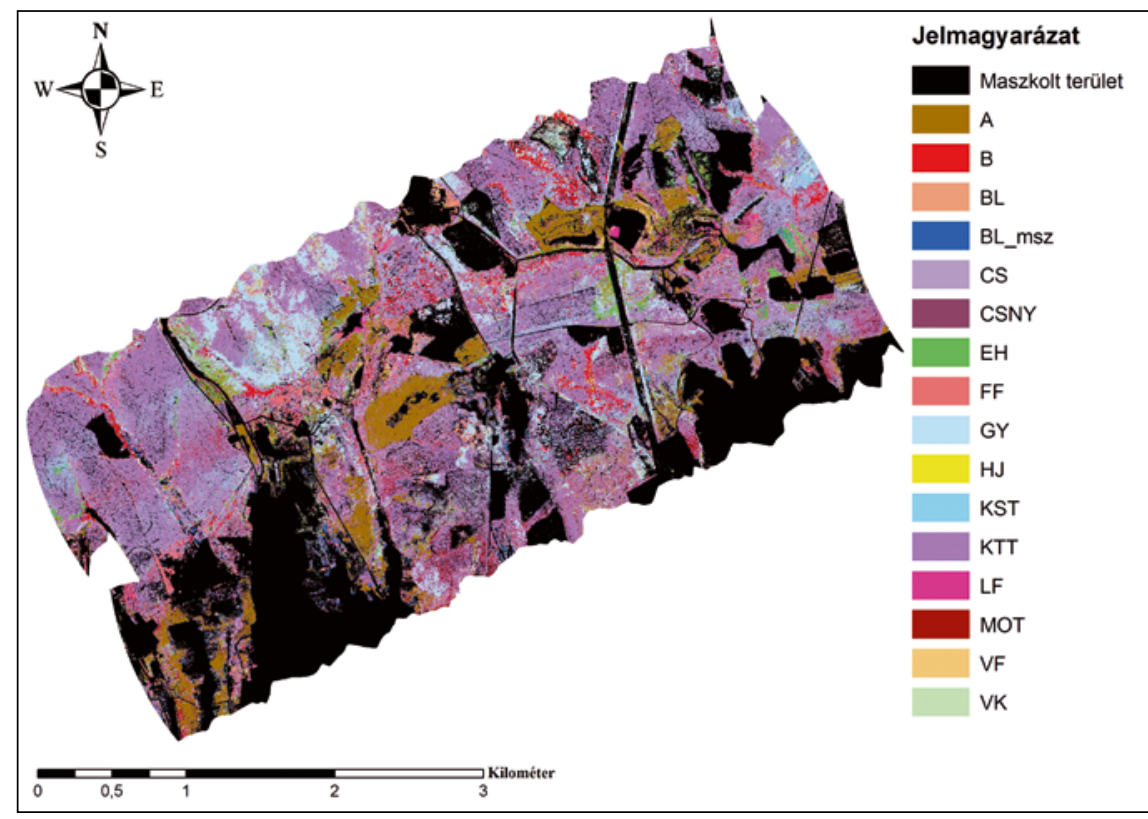

4. ábra. A teljes vizsgálati terület 18 MNF-csatornát alkalmazó SVM-osztályozásának eredménye

legmagasabb elért teljes pontossági értéket nézve.

Az egyes osztályozási típusok más és más transzformált csatornaszám bevonásánál érték el a maximális teljes pontosságukat. Az azonos osztályozási típusnál, de különbözô transzformált csatornákkal is eltérô eredmény látszik. Ez újabb okot ad a módszer kutatására. Alátámasztható, hogy az osztályozásoknál nincsen meghatározott csatornaszám a legpontosabb eredmény elérésére. Szükséges tehát a különbözố osztályozásoknál a csatornaszámok változtatásával tesztelni a hatékonyságot.

A Mecsek lábánál elterülố vizsgált erdôs területen a legjobb transzformációtípusnak az MNF bizonyult, a leghatékonyabb osztályozási algoritmusnak pedig az SVM. Olyannyira, hogy minden vizsgált csatornaszámnál ez a kombináció hozta a legmagasabb teljes pontosságot, számos kutatásban és vizsgálatban alkalmazzák; különbözó területeken is gyakran ez a típus hozza a legjobb eredményeket (MelganiBruzzone 2004).

A tanítóterületek növelésével az osztályozások hatékonysága javítható. Jobb eredménnyel szolgálhatott volna, ha egységesen magasabb a pixelszám a területen, egyenletes eloszlásban, ez természetesen a gyakorlatban ritkán fordul elô, mivel a fafajok eloszlása sem egyenletes. Habár itt megjegyzendő, hogy ahol a tanítóterületek nem érték el a 100 pixel méretet ott nem hoztak egyértelmúen rosszabb eredményt a többi osztálynál, kivéve a lucfenyôt, mely így is kiemelkedő pontosságot mutatott. 


\section{Összefoglalás}

Mindezt összevetve az MNF transzformált csatornák SVM-algoritmussal történô osztályozását tudjuk felmutatni mint a leghatékonyabb módszert, melynek teljes osztályozási pontossága elérte a $81,16 \%$-os értéket, a maximális rendelkezésre álló tanítóterületek felhasználásával. Ez az eredmény a felmért mintaterület 10 osztályának az összessége, amit a bálványfaosztályok (BL, BL_msz) összevonásával értünk el, melyre a nagymértékú keveredés adott okot. Az eredmény erre az osztályszámra vonatkozólag is a technológia jó használhatóságát mutatja. A teljes pontossági értékek mellett jelentős eredményt hozott a fafajok osztályozási eredményének külön-külön történô elemzése, mely alapján meg lehet különböztetni a nehezen és a jól osztályozható fafajokat. A legmagasabb pontossági értéket a hegyi juhar, a lucfenyô, az ezüst hárs és az akác mutatta, szemben a madárcseresznyével és a bálványfával. A teljes terület vizsgálatánál az eredmény elmaradt az előbbihez képest, ahogy az várható is volt; itt a számos, mintegy 16 osztály megkülönböztetése nagyobb hibafaktort jelentett, de ezzel együtt is $70,20 \%$-os teljes pontossági értéket jelzett.

\section{Köszönetnyilvánítás}

Köszönetünket fejezzük ki az Envirosense Hungary Kft.-nek és a Mecsekerdő Zrt.-nek a kutatásban való közremúködésükért, a rendelkezésünkre bocsátott adatokért és erôforrásokért. A tanulmány alapjául szolgáló kutatást az Innovációs és Technológiai Minisztérium által meghirdetett Tématerületi Kiválósági Program (TKP2020-NKA-04) támogatta. Likó Szilárd Balázs munkája az Innovációs és Technológiai Minisztérium Kooperatív Doktori Program Doktori Hallgatói Ösztöndíjprogramjának a Nemzeti Kutatási, Fejlesztési és Innovációs Alapból finanszírozott szakmai támogatásával készült.

\section{Irodalom}

Belgiu, M. - Drăgut, L. 2016. Random forest in remote sensing: A review of applications and future directions. ISPRS Journal of Photogrammetry and Remote Sensing 114, pp. 24-31.

DOI: $10.1016 /$ j.isprsiprs.2016.01.011

Burai, P. - Bekô, L. - Lénárt, C. - Tomor, T. - Kovács, Z. 2019. Individual Tree Species Classification Using Airborne Hyperspectral Imagery And Lidar Data. 10th Workshop on Hyperspectral Imaging and Signal Processing: Evolution in Remote Sensing pp. 1-4.

Burai, P. - Bekô, L. - Lénárt, C. - Tomor, T 2014. Classification of energy tree species using support vector machines. 6th Workshop on Hyperspectral Image and Signal Processing: Evolution in Remote Sensing (WHISPERS).

DOI: 10.1109/whispers.2014.8077499

Clark, M. L. - Roberts, D. A. - Clark, D. B. 2005. Hyperspectral discrimination of tropical rain forest tree species at leaf to crown scales. Remote Sensing of Environment 96 , pp. 375-398. DOI: $10.1016 /$ i.rse.2005.03.009

Deák Márton - Telbisz Tamás - Árvai Mátyás - Mari László - Horváth Ferenc - Kohán Balázs - Szabó Orsolya - Kovács József 2017. Heterogeneous forest classification by creating mixed vegetation classes using EO-1 Hyperion. International Journal of Remote Sensing 38, pp. 5215-5231. DOI: $10.1080 / 01431161.2017 .1325529$

Hamada, Y. - Stow, D. A. - Coulter, L. L. Jafolla, J. C. - Hendricks, L. W. 2007. Detecting Tamarisk species (Tamarix spp.) in riparian habitats of Southern California using high spatial resolution hyperspectral imagery. Remote Sensing of Environment 109 , pp. $237-248$

DOI: $10.1016 /$ i.rse.2007.01.003

Kovács, Z. - Burai, P. - Bekô, L. - Varga, O. Lénárt, Cs. - Hunyadi, G. - Tomor, T. 2019 Invasive tree species detection based on the fusion of hyperspectral images and LiDAR data. Geophysical Research Abstracts 21, p. 1

Latifi, H. - Fassnacht, F. - Koch, B. 2012 Forest structure modeling with combined airborne hyperspectral and LiDAR data. Remote Sensing of Environment, 121, pp. $10-25$

DOI: $10.1016 /$ i.rse.2012.01.015

Melgani, F. - Bruzzone, L. 2004. Classification of Hyperspectral Remote Sensing Images With Support Vector Machines. IEEE Transactions on Geoscience and Remote Sensing, 42. pp. 1778-1790. DOI: $10.1109 /$ tgrs.2004.831865

Rasti, B. - Scheunders, P. - Ghamisi, P. Licciardi, G. - Chanussot, J. 2018. Noise Reduction in Hyperspectral Imagery: Overview and Application. Remote Sensing, 10(3), 482 DOI: $10.3390 / \mathrm{rs} 10030482$

Richter, R - Reu, B - Wirth C - Doktor, D. - Vohland, M. 2016. The use of airborne hyperspectral data for tree species classification in a species-rich Central European forest area. International Journal of Applied Earth Observation and Geoinformation, 52, pp. 464-474. DOI: $10.1016 /$ i.jag.2016.07.018
Tarabalka, Y. - Chanussot, J. - Benediktsson, J. A. 2010. Segmentation and Classification of Hyperspectral Images Using Minimum Spanning Forest Grown From Automatically Selected Markers. IEEE Transactions on Systems, Man, and Cybernetics, Part B (Cybernetics), 40(5), pp. 1267-1279. DOI: $10.1109 /$ tsmcb.2009.2037132

Zhang, C. - Xie, Z. 2012. Combining object-based texture measures with a neural network for vegetation mapping in the Everglades from hyperspectral imagery. Remote Sensing of Environment 124, pp. 310-320. DOI: 10.1016/i.rse.2012.05.015

Zhong, Y. - Wang, X. - Xu, Y. - Wang, S. Jia, T. - Hu, X. - Zhang, L. 2018. Mini-UAVBorne Hyperspectral Remote Sensing. From Obervation and Processing to Applications. IEEE Geoscience and Remote Sensing Magazine 6(4), pp. 46-62 DOI: $10.1109 /$ mgrs.2018.2867592

Erdôtérkép hivatalos honlapja: https://erdoterkep.nebih.gov.hu/

Harris geospatial solutions inc. hivatalos honlapja: www.harrisgeospatial.com

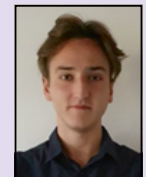

Likó Szilárd Balázs doktorandusz

Eötvös Loránd Tudományegyetem Földtudományi Doktori Iskola liko.szilard.balazs@gmail.com

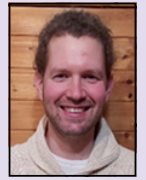

Bekố László tudományos segédmunkatárs

Debreceni Egyetem, Távérzékelési Szolgáltató Központ beko.laszlo@unideb.hu

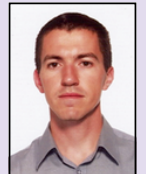

Dr. Burai Péter tudományos fömunkatárs

Debreceni Egyetem, Távérzékelési Szolgáltató Központ burai.peter@unideb.hu

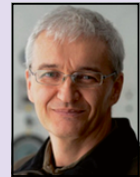

Dr. Mari László egyetemi docens

Eötvös Loránd Tudományegyetem, TTK FFI Természetföldrajzi Tanszék laszlo.mari@ttk.elte.hu 